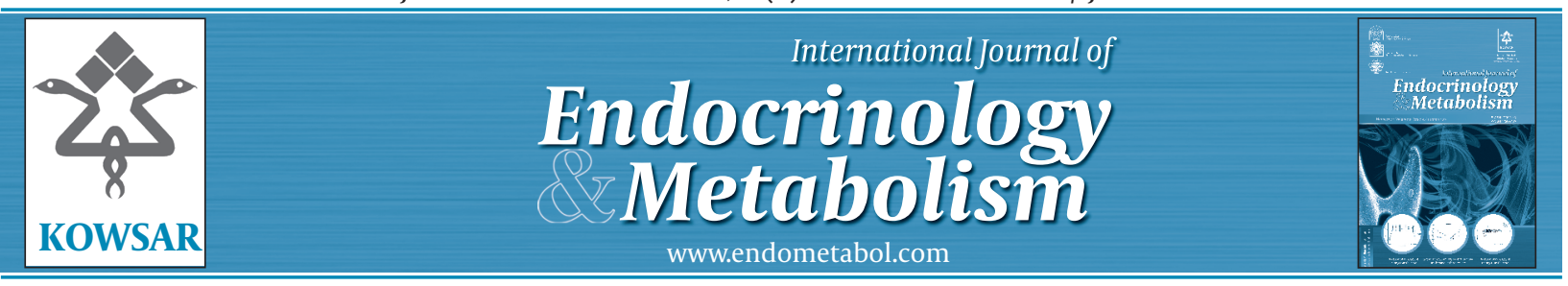

\title{
Physical Activity as a Strategy to Reduce the Risk of Osteoporosis and Fragility Fractures
}

\author{
Magnus Karl Karlsson ${ }^{1 *}$, Bjorn Erik Rosengren ${ }^{1}$ \\ ${ }^{1}$ Clinical and Molecular Osteoporosis Research Unit, Department of Clinical Sciences, Lund University, Department of Orthopaedics, Skane University \\ Hospital, Malmo, Sweden
}

\begin{tabular}{l}
\hline A R T I C L E I N F O \\
\hline Article type: \\
Review Article \\
\hline Article history: \\
Received: 25 Oct 2011 \\
Revised: 27 Feb 2012 \\
Accepted: 08 Mar 2012 \\
\hline
\end{tabular}

Keywords:

Osteoporosis

Physical Activity

Athletes

\begin{abstract}
A B S T R A C T
Childhood and adolescence are critical periods for the skeleton. Mechanical load has then been shown to be one of the best stimuli to enhance not only bone mass, but also structural skeletal adaptations, as both contributing to bone strength. Exercise prescription also includes a window of opportunity to improve bone strength in the late pre- and early peri-pubertal period. There is some evidence supporting the notion that skeletal gains obtained by mechanical load during growth are maintained at advanced age despite a reduction of physical activity in adulthood. The fact that former male athletes have a lower fracture risk than expected in their later years does not oppose the view that physical activity during growth and adolescence is important and it should be supported as one feasible strategy to reduce the future incidence of fragility fractures.
\end{abstract}

Publish by Kowsar Corp. All rights reserved.

Implication for health policy/practice/research/medical education:

Available data indicate that physical activity during growth and adolescence probably reduces the future incidence of fragility fractures.

Please cite this paper as:

Karlsson MK, Erik Rosengren B. Physical Activity as a Strategy to Reduce the Risk of Osteoporosis and Fragility Fractures. Int J Endocrinol Metab. 2012;10(3):527-36. DOI: 10.5812/ijem.3309

\section{Introduction}

The skeleton is a metabolically active organ that responds to mechanical stimuli by initiating or inhibiting bone modelling and remodelling in order to keep peak strains within a safe physiological range. Up to $40 \%$ of the variance in bone strength is also estimated to be determined by the mechanical load that it supports (1). The feedback system, where the skeletal response depends on the characteristics of the load, is usually referred to after the mechanostat, a theory popularized by Harold Frost (2). Key features for osteogenic stimuli include a load that

${ }^{*}$ Corresponding author: Magnus Karlsson, Department of Clinical Sciences and Orthopaedics, Skane University Hospital, Lund University, SE - 20502 Malmo, Sweden. Tel: +46-40331000, Fax: +46-40336200, E-mail: magnus. karlsson@med.lu.se

DOI: $10.5812 /$ ijem.3309

Copyright @2012 RIES \& IES. Publish by Kowsar Corp. All rights reserved. is dynamic, has a high magnitude, a high frequency and unusually distributed strains (3-5). The required mechanical load necessary to stimulate osteogenesis also decreases as the strain magnitude and frequency increases (3-5). But the osteogenic response to mechanical load becomes saturated after a few loading cycles (6). Following this, any additional load provides limited further benefit (7). However, bone cell mechanosensitivity recovers following rest so that separating loading into short bouts with periods of rest in between optimises the osteogenic response to loading (8-10). For example, four hours of rest between loads doubles the osteogenic response and the sensitivity to loading is almost completely restored after eight hours of recovery, as shown in animal studies (11). That is, the loading characteristics most beneficial for bone strength are very specific, making a general prescription of physical activity for cardiovascular health or weight reduction non-optimal for skeletal health. 
There are currently many studies that have shown exercise to be associated with higher bone mineral density (BMD) (12-29) and lower fracture incidence (30-32) than expected by age and gender. The osteogenic response are also maturity and gender dependent $(18,33)$ so that the strongest response to mechanical stimuli occurs during growth, especially in the pre- or early pubertal period (12$29,33-35)$. The response in adults is lower, in that physical activity can only reduce age related bone loss or at best produce increments in BMD of just a few percentage points $(36,37)$. These benefits are of questionable clinical significance for fracture reduction. The lower fracture incidence in physically active elderly people is therefore, probably the result of non-skeletal effects such as; increased muscle strength and/or improved neuromuscular function, traits which are possible to influence by training even in the tenth decade of life (38). Training in the elderly should therefore be structured to reduce the risk of falling, more than to prevent osteoporosis, if the aim is to reduce the incidence of fragility fractures (39).

\section{Objectives}

The objective of this review is to evaluate the skeletal effects of exercise through physical activity during growth and if exercise induced skeletal effects are retained with associated fracture reduction at older ages. This report is not a structured review, it is a review that primarily includes prospective controlled trials, preferably randomized studies found in PUBMED, that evaluate the skeletal effects of interventions with physical activity in the earlier years of life and the long term effects of exercise at reduced activity levels.

\section{Exercise and the Skeleton in Athletes}

The relationship between physical activity and an increase in BMD during the first two decades in life was reported 40 years ago when Nilsson et al. found that athletes had higher BMD than controls (40). This view has been supported in a variety of further articles that found that high impact sports such as tennis, squash, gymnastics, ice-hockey, volleyball and soccer are associated with a higher than expected BMD, while the practices of endurance sports such as; running, cycling and swimming showed less promising results (41). For example, in young female gymnasts, BMD has been shown to increase 30 to $85 \%$ more rapidly than in sedentary children (42), but young tennis players display a 10-15\% arms side-to-side difference in $\operatorname{BMD}(18,43)$. The difference is also more pronounced if the exercise is initiated before, rather than after puberty $(18,43)$. That is, much of our knowledge as regard to the adaption of the skeleton when exposed to increased mechanical load has been achieved from studies on athletes. However, these results provide us with information on what is possible, rather than what is prob- able, to reach by physical activity in children.

\section{General Physical Activity and the Skel- eton at Growth}

Studies in children with a moderate general level of physical activity have shown that exercise intervention is associated with skeletal benefits, but this is of lower magnitude than in athletes (12-29, 33-35) (Table 1). These benefits should, however, not be underestimated as even a small increase in bone mass can generate a more than two-fold increase in bone strength $(8,9,44)$. Most intervention studies in pre- and peri-pubertal children utilize extra physical education classes or supplementary exercise in addition to physical education classes and most studies are short-term of less than 12 months duration $(13,15-17,19,20,24,25,28,29,34,45)$. But, there are now a few reports of up to a 5 year follow-up period that infer that long term moderate to intense interventions on a population based level may provide beneficial skeletal effects $(14,20-23,26,46)$ (Figure 1). These interventions can also be initiated without inducing an increased rate of childhood fractures $(14,21)$, an adverse effect of physical activity that has been postulated to occur when increasing the rate of trauma during periods of intense levels of physical activity (47-49). The reason for the maturity and sex-dependent response to mechanical load $(18,33)$ is postulated to be the result of exercise preferentially affecting surfaces of the bone undergoing apposition and hormonal discrepancies (50). The pre-pubertal skeleton also seems to have the capacity to respond to loading by adding more bone on the periosteal surface than would normally occur through growth-induced periosteal apposition $(43,51,52)$. Although studies also infer that an endosteal apposition exists in pre-pubertal boys as a response to mechanical load $(13,51,53)$, whereas such a response seems less likely in pre-pubertal girls $(43,53)$. Exercise in late puberty is associated with bone apposition

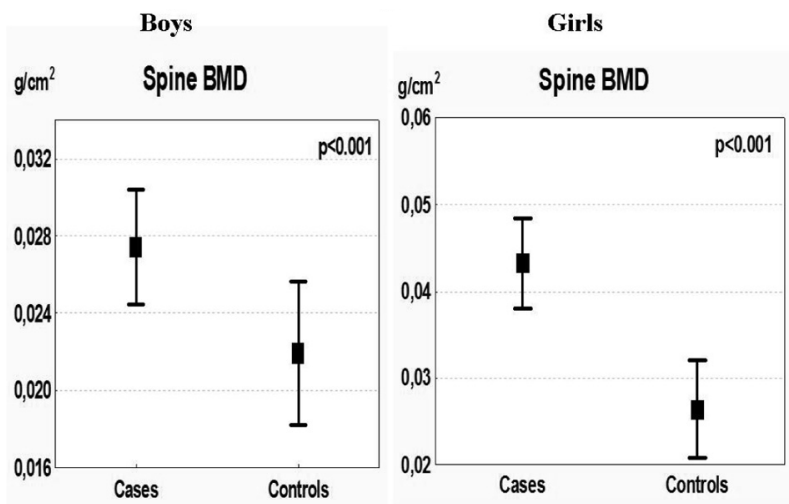

Figure 1. Mean Annual Changes in Lumbar Spine Bone Mineral Density (BMD) in Boys and Girls during the 5-year Intervention Presented as Means with $95 \%$ Confidence Intervals 


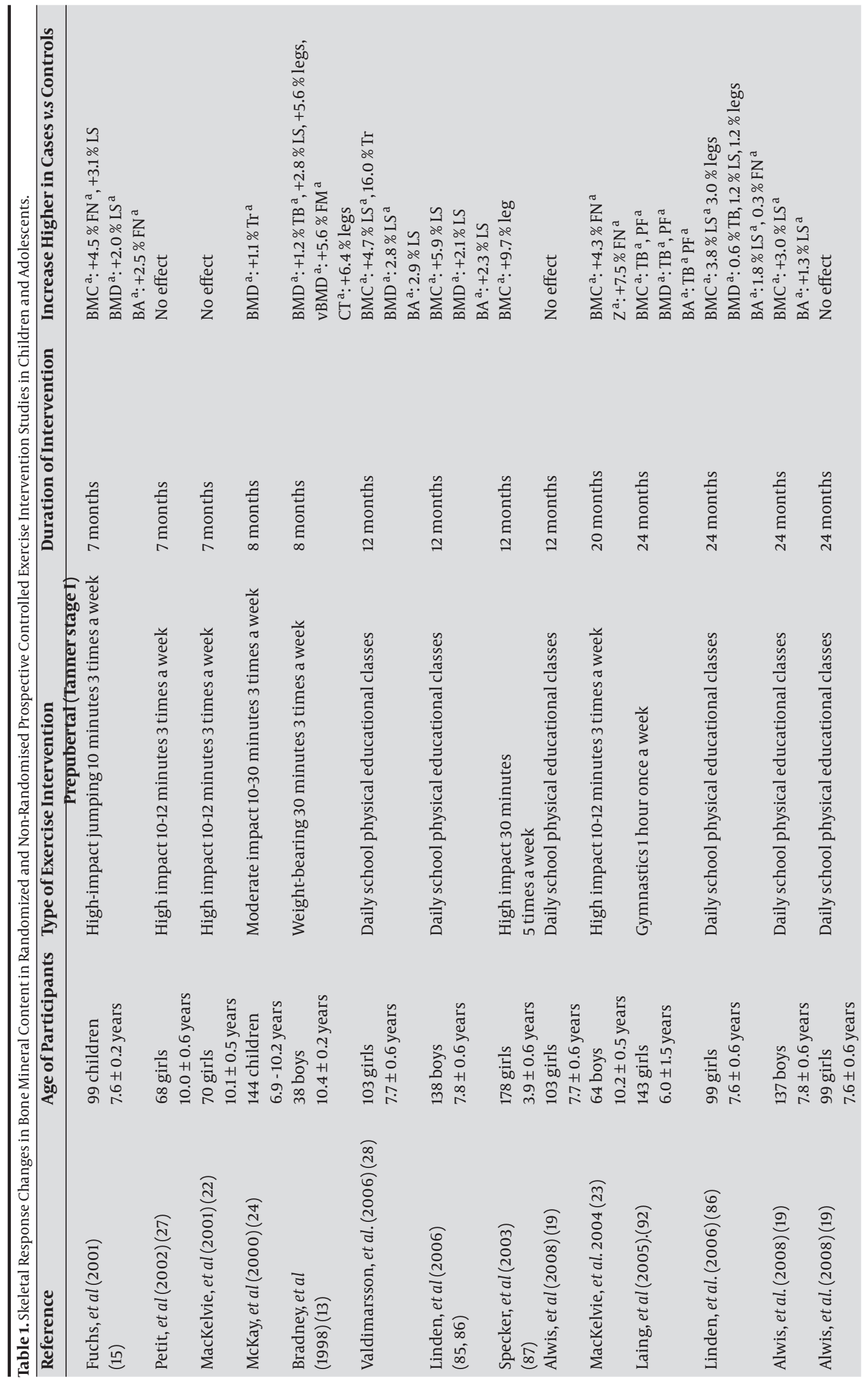




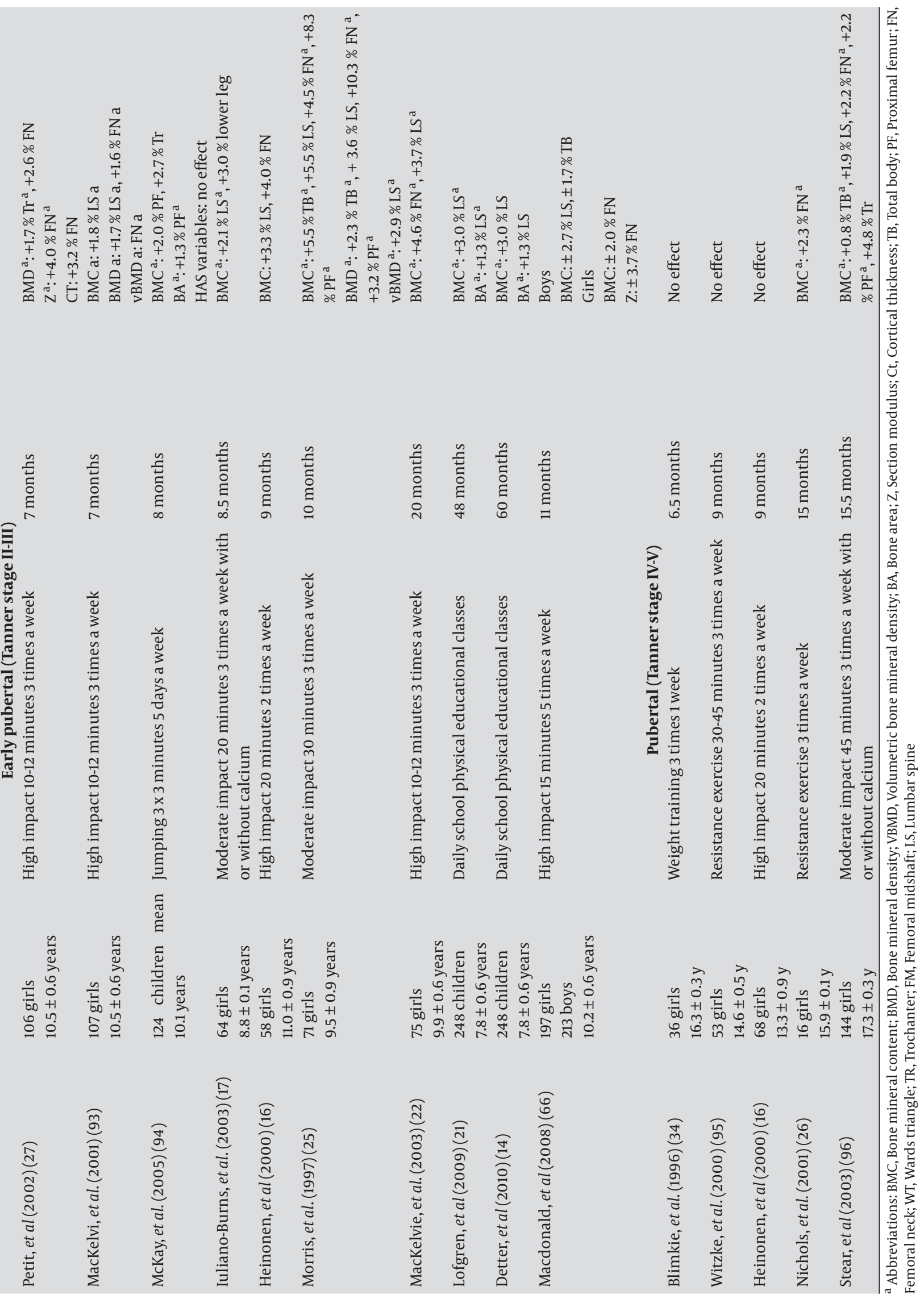


on the endosteal surface, as shown in female tennis players (43), and the enlargement of bone size in response to loading has been reported to increase from pre- to peripuberty in male, but not in female tennis players $(43,51)$. These differences confer in general a more beneficial response in boys than in girls.

The effect of physical activity on periosteal apposition is also translated to a greater increase in bone strength than an increase in bone mass alone $(43,54,55)$. Three-dimensional techniques such as the peripheral quantitative computed tomography (pQCT) and magnetic resonance imaging (MRI) have identified periosteal expansion at loaded sites in physically active individuals. For example, bone size was approximately $10 \%$ higher in the upper limbs of young pre-pubertal gymnasts than in children on an average level of physical activity $(52,53)$. The arms side-to-side difference in bone size was also obvious in young pre-pubertal tennis players $(43,51)$. Bone may also be laid down on the endosteal surface so that the cortical thickness increases. For example, there are reports that infer that the cortical cross-sectional area can be 5 to $12 \%$ greater in the lower limbs of young runners or gymnasts compared to controls in spite of both having the same bone size $(53,56,57)$. The endosteal apposition is, however, less beneficial than the periosteal apposition if the goal is to increase bone strength, as the bone resistance to bending increases by the forth power of the radial distance (58-60).

In addition, the osteogenic response in the upper and lower limbs appears to be site-specific $(53,61)$. For example, endosteal apposition has also been found at the $60-70 \%$ distal humerus, but not at the $40-50 \%$ mid humerus in young tennis players $(43,51)$ and there is a different response to mechanical load in the anterior-posterior compared to the medial-lateral direction and in the proximal, mid-diaphysis and distal part of the long bones $(8,53,54,61,62)$. If these regional discrepancies in the response to mechanical loading are the result of different types of loads in different regions, different thresholds for osteogenesis response in different regions, or different load magnitudes relative to bone size in different regions is unknown.

The strength of the bone could also be increased by the redistribution of bone mass to areas submitted to high mechanical strains. Bone strength can thus be increased by changing the shape of the bone, without an accompanying increase in bone mass or bone size, an adaptive model that has been reported in both animals $(8,44$, $63,64)$ and humans $(45,65,66)$. Furthermore, there are also reports that infer bone mass to be transferred from unloaded to skeletal loaded parts during high intensity activity $(67,68)$. However, there are a range of different study designs, some of the cited studies are randomized, others non-randomized, some studies include only a few individuals. In the different studies there are different types of activities used in the intervention, different intensity levels and different frequencies advocated, different drop-out rates and different leisure time activities accepted, all facts that could influence our conclusions.

\section{Are the Bone Mass Benefits Gained dur- ing Growth Preserved with Cessation of Ex- ercise?}

The exercise-induced skeletal benefits obtained during growth can, however, not be considered of clinical relevance as a preventive strategy for osteoporosis and fragility fractures unless the benefits are maintained into old age. Hypothetically, this seems less likely as the mechanostat theory indicates a decrease in bone strength as a response to reduced levels of physical activity $(2,69)$. Prospective studies that evaluate changes in the skeleton after a reduction in physical activity levels have been inconclusive. Seven years after an exercise intervention program in pre-pubertal children there were still significant skeletal benefits in the intervention group (70) and

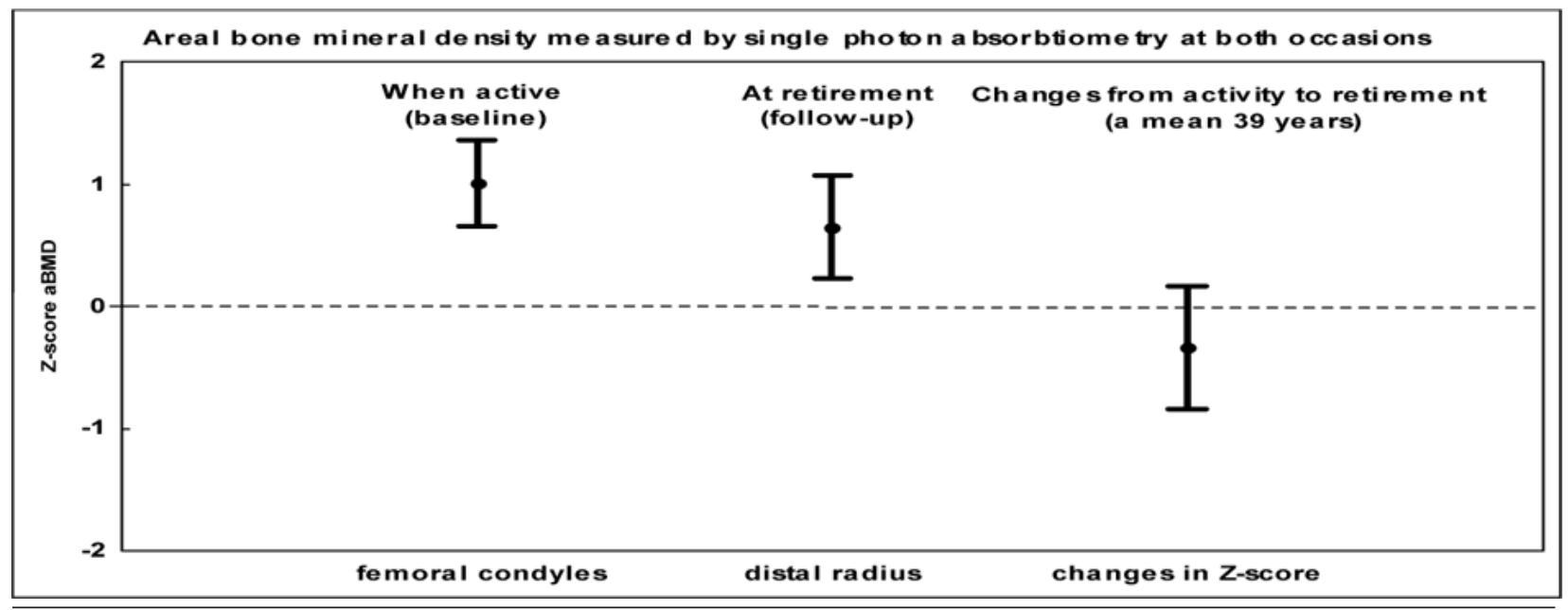

Figure 3. Bone Mineral Density (BMD) and Muscle Strength in 46 Male Athletes, at Baseline Median 19 (15-40) Years and 38-40 Years Later Presented as Means with $95 \%$ Confidence Intervals. 
former elite gymnasts aged 18-35 years, who had been retired for 8 years displayed greater bone mass compared to the age-matched controls (42). This was due to a greater bone size, cortical area and trabecular volumetric density in the upper limbs and greater cortical area and trabecular volumetric density in the tibia (71). However, the residual benefits were smaller than those found during

Figure 4. Fracture Free Survival in 709 Former Male Athletes Retired from Sports after Retirement from Sports and 1368 Matched Controls.

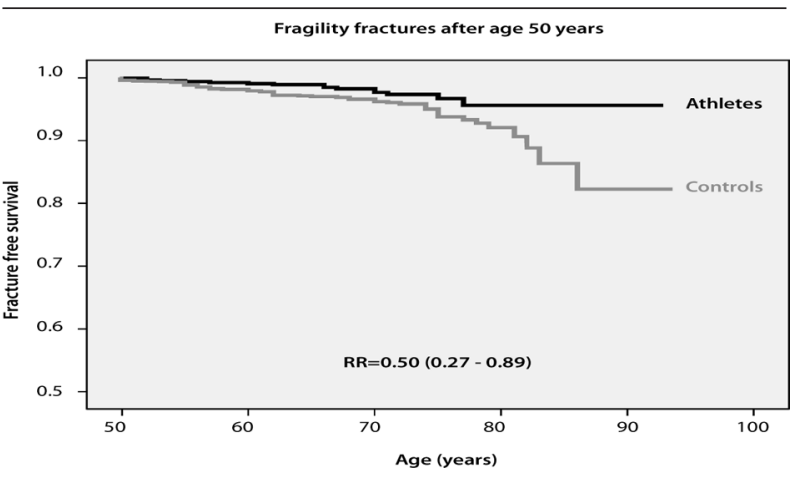

Rate Ratio (RR) is Presented as Mean with $95 \%$ Confidence Interval

their exercise career. The same was found in prospective studies following male and female soccer players that reported that a decade after retirement from the sport, there was a greater BMD loss in the former athletes and that conferred only half of the benefits found in active athletes after 5-10 years of retirement from the sport (72, 73). Kontulainen et al. presented similar data in racket players when they reported that the dominant and nondominant arm differences in bone mass remained after a reduction in physical activity level, but at a lower level (74). There is now also prospective, controlled study data which infers that exercise induced benefits in BMD are retained following long term retirement (Figure 2 and Figure 3). The exercise induced higher BMD in male athletes at 53-79 years of age, and after a mean of three decades of retirement from an active sports career, was still higher than expected by age, and the risk of sustaining a fragility fracture was only half when compared to the control cohort (49) (Figure 4). Unfortunately, there was no prospective structural evaluation of the skeleton performed in this report, even if cross sectional data at follow-up also inferred benefits in bone structure in favour of the former athletes. This study indicates that the faster loss in BMD found immediately after a reduction in physical activity levels could be transient.

Other reports refute the notion that exercise induced skeletal benefits are retained after an active career. This would not be unexpected, as Wolff's law suggests that the skeleton adapts to the current level of mechanical load. Prospective data infers that there is an increased bone loss in former runners, whereas there was no loss found in those who continued with their running (75). Vuori et al. supports this

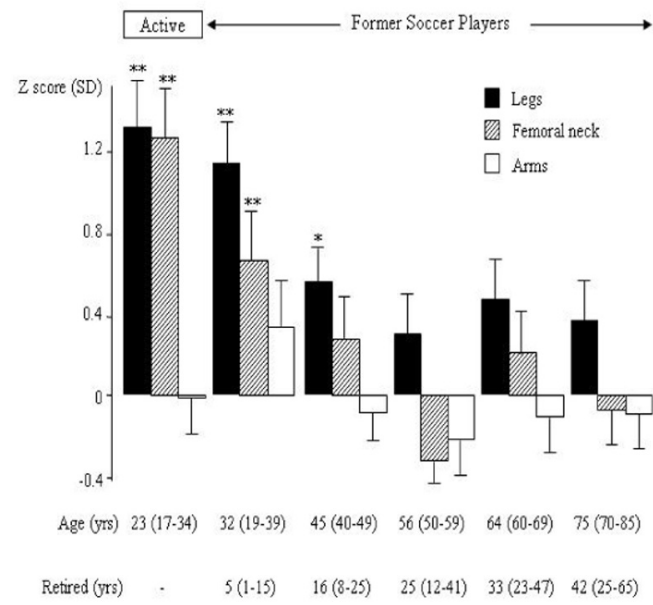

Figure 2. Bone Mineral Density (BMD) of the Lower Extremity, Femoral Neck and Upper Extremity in Active and Retired Male Soccer Players and Controls in Relation to Age Presented as Mean with standard deviations (SD).

view when reporting that unilateral leg presses four times a week during a 12 month period produced non-significant increases in bone mass, probably due to the relive short duration of training, but the BMD returned to pre-training levels within three months of non-training (76). Cross-sectional studies show similar results when reporting that former male soccer players have a higher residual BMD during the first two decades after retirement, but four to five decades later, only a non-significant higher leg BMD remained in the former athletes (77) (Figure 2). Virtually the same conclusions have been reported in former female soccer players (78), former male weight lifters $(68,79-81)$, and former male and female ballet dancers $(82,83)$, a common view that is now being opposed by recently published prospective controlled reports with the longest follow-up period into retirement so far (49) (Figure 3). However, most of our data in regard to the long-term effects of exercise are derived from cross-sectional studies, with the risk of being affected by secular trends in training intensity and selection bias at the baseline. Furthermore, most reported prospective studies are short-term studies that have not followed the former athletes from their active career for a maximum of three decades, that is only into ages when fragility fractures have still not become a problem of any magnitude. Also, these studies include the risk of a selection bias, as the athletes already had a higher bone mass than controls at baseline.

\section{Are Bone Structural Benefits Gained at Growth Preserved with Cessation of Exer- cise?}

As the mature skeleton is thought to lose bone mass essentially through remodelling on the endosteal envelope, and to a much lower extent on the periosteal envelope (84), the structural adaptations obtained by physical activity during growth periods (85-87) may be better preserved (41). This 
would be of clinical importance as bone structure contributes to the skeletal resistance to fractures, independently of bone mass (59). Haapasalo et al. reported an exercise-associated enlargement in bone size (humerus, radius shafts, and distal humerus) in former racket players, without a change in volumetric bone density (vBMD; $\mathrm{g} / \mathrm{cm}^{3}$ ) which was maintained after retirement (54). Former male tennis players who had been retired for 1 to 3 years had a higher, side to side difference when comparing dominant and non dominant arms with; bone mineral content (BMC) (20\%), total cross-sectional area of bone (18\%), cortical area (22\%), bone strength index (30\%) and cortical wall thickness (15\%). The side-to-side difference in the cross-sectional area of the marrow cavity was higher at the proximal humerus (19\%) and radial shaft (29\%). These observations fit with the notion that exercise produces an enlargement of bone size that is permanent after retirement, while any endocortical thickening due to endocortical apposition may be lost or partly lost after retirement, resulting in a gradual loss in the BMD benefits. Also, in children aged 3 to 5 years, reports infer that exercise induced benefits in bone structure remained after an intervention program, at least in a short term perspective (88). There is, however, limited data in 70 to 80 year old retired athletes, the ages when fragility fractures rise exponentially. These studies suggest that the exerciseinduced benefits in BMD may be eroded in those who have substantially decreased their training volumes (77), while structural benefits may persist (89). In the same cited study, the femoral neck area and lumbar spine width was reported to be larger in former male athletes, who were all above the age of 50 years and had been retired from exercise for up to 65 years, than in sedentary controls (89). Although, as the study was cross sectional, these differences could also be based on selection bias.

\section{Are Exercise Induced Skeletal Benefits in Bone Mass Gained during Growth Pre- served with Recreational Exercise?}

The importance of recreational training after a high intensity training period is also supported in a variety of studies. Current training was of more importance than the previous training level in the younger years of male soccer players (77) and Huddlestone et al. reported that an arm to arm difference of 4-7\% remained in older aged former tennis players, if they continued with recreational tennis (90). These studies support the notion that recreational exercise following a period of high intensity training during younger years, may at least partly preserve exercise-induced bone mass benefits at a later stage in life.

\section{Is Exercise during Younger Years fol- lowed by Reduced Fracture Incidence at Ad- vanced Age?}

If exercise induced structural skeletal benefits are re-

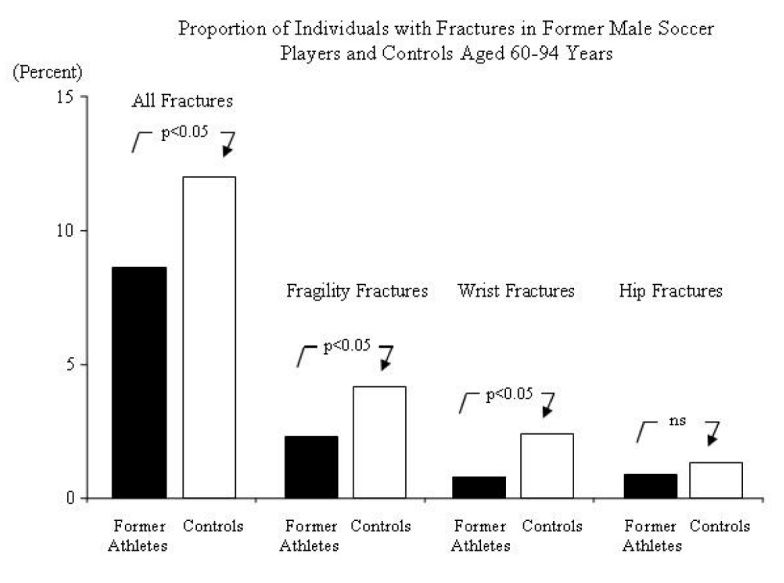

Figure 5. Proportion of Individuals with One or More Fractures in 663 Former Male Athletes and 943 Age and Gender Matched Controls.

tained into old age, hypothetically this ought to be associated with a lower risk of fractures than expected by age and gender. A reduced fracture risk has also been reported in retired athletes. The prevalence of fractures in 663 former athletes above the age of 50 years, and retired from sports for up to 65 years were lower than in 943 age and gender matched controls, $8.9 \%$ in the former athletes and $12.1 \%$ in the controls (72) (Figure 5). Additionally, the proportion of subjects with low energy fragility fractures sustained after 50 years of age was lower in the former athletes compared to the controls, $2.3 \%$ versus $4.2 \%$, as well as the proportion of individuals with distal radius fractures, $0.8 \%$ versus $2.3 \%$. Similar conclusions have been reported in one trial evaluating 400 former male soccer players and 800 controls (89) and now there has also been an epidemiological study published that includes 2075 former male athletes and controls aged 50-91 years, the study reports a lower incidence of all types of fractures including fragility fractures and distal radius fractures in the former sportsmen (49) (Figure 4). But other studies refute this view. An often cited study includes 2622 former female college athletes and 2776 controls now aged 20-80 years, a trial that reported a similar fracture risk in both groups, $29 \%$ versus $32 \%$ (91). However, as this study includes individuals with as low an age as 20 years with an extremely short period of both exercise career and retirement period, and with different levels of recreational exercise after retirement, the data is difficult to interpret.

\section{Conclusions and Perspective}

Childhood and adolescence are critical periods for the skeleton. Mechanical load has been shown during this period to be one of the best stimuli to enhance, not only bone mass, but also structural skeletal adaptations, both contributing to bone strength. Exercise prescription also includes a window of opportunity to improve bone strength in the late pre- and early peri-pubertal period. There is some evidence supporting the notion that skel- 
etal gains obtained by mechanical load during growth are maintained at an advanced age, despite a reduction of physical activity in adulthood, and the notion that former male athletes have a lower fracture risk than expected by age, at least does not oppose the view that physical activity during growth and adolescence should be supported as one feasible strategy to reduce the future incidence of fragility fractures. However, as the conclusions discussed above are drawn predominantly from non-randomised studies and studies that include surrogate end points as bone mass, there is a need for future randomized controlled trials and studies that use the clinical relevant end-point, fractures, when evaluating if physical activity could be used as a strategy to reduce the number of fractures in older people in society.

\section{Acknowledgments}

None declared.

\section{Financial Disclosure}

None declared.

\section{Funding/Support}

None declared.

\section{References}

1. Frost HM, Schonau E. The "muscle-bone unit" in children and adolescents: a 2000 overview. J Pediatr Endocrinol Metab. 2000;13(6):571-90.

2. Frost HM. Bone "mass" and the "mechanostat": a proposal. Anat Rec. 1987;219(1):1-9.

3. Cullen DM, Smith RT, Akhter MP. Bone-loading response varies with strain magnitude and cycle number. J Appl Physiol. 2001;91(5):1971-6.

4. Hsieh YF, Turner CH. Effects of loading frequency on mechanically induced bone formation.J Bone Miner Res. 2001;16(5):918-24.

5. Turner $\mathrm{CH}$. Three rules for bone adaptation to mechanical stimuli. Bone. 1998;23(5):399-407.

6. Rubin CT, Lanyon LE. Regulation of bone formation by applied dynamic loads. J Bone Joint Surg [Am].1984;66(3):397-402.

7. Umemura Y, Ishiko T, Yamauchi T, Kurono M, Mashiko S. Five jumps per day increase bone mass and breaking force in rats. $J$ Bone Miner Res. 1997;12(9):1480-5.

8. Robling AG, Hinant FM, Burr DB, Turner $\mathrm{CH}$. Improved bone structure and strength after long-term mechanical loading is greatest if loading is separated into short bouts.J Bone Miner Res. 2002;17(8):1545-54

9. Robling AG, Hinant FM, Burr DB, Turner CH. Shorter, more frequent mechanical loading sessions enhance bone mass. Med Sc Sports Exerc. 2002;34(2):196-202.

10. Srinivasan S, Weimer DA, Agans SC, Bain SD, Gross TS. Low-magnitude mechanical loading becomes osteogenic when rest is inserted between each load cycle. J Bone Miner Res. 2002;17(9):1613-20.

11. Robling AG, Burr DB, Turner CH. Recovery periods restore mechanosensitivity to dynamically loaded bone. J Exp Biol. 2001;204(Pt 19):3389-99.

12. Bass SL, Naughton G, Saxon L, Iuliano-Burns S, Daly R, Briganti EM, et al. Exercise and calcium combined results in a greater osteogenic effect than either factor alone: a blinded randomized placebo-controlled trial in boys. J Bone Miner Res. 2007;22(3):458-64

13. Bradney M, Pearce G, Naughton G, Sullivan C, Bass S, Beck T, et al.
Moderate exercise during growth in prepubertal boys: changes in bone mass, size, volumetric density, and bone strength: a controlled prospective study [see comments]. J Bone Miner Res. 1998;13(12):1814-21.

14. Detter F, Nilsson J- $\AA$, Karlsson M. A Five Years Exercise Intervention Program in 7-9 Years Old Children Improve Bone Mass and Bone Structure without Increasing the Fracture Incidence.J Bone and Miner REs. 2010;25(1).

15. Fuchs RK, Bauer JJ, Snow CM. Jumping improves hip and lumbar spine bone mass in prepubescent children: a randomized controlled trial. J Bone Miner Res. 2001;16(1):148-56.

16. Heinonen A, Sievanen H, Kannus P, Oja P, Pasanen M, Vuori I High-impact exercise and bones of growing girls: a 9-month controlled trial. Osteoporos Int. 2000;11(12):1010-7.

17. Iuliano-Burns S, Saxon L, Naughton G, Gibbons K, Bass SL. Regional specificity of exercise and calcium during skeletal growth in girls: a randomized controlled trial. J Bone Miner Res. 2003;18(1):156-62.

18. Kannus P, Haapasalo H, Sankelo M, Sievanen H, Pasanen M, Heinonen A, et al. Effect of starting age of physical activity on bone mass in the dominant arm of tennis and squash players. Ann Intern Med.1995;123(1):27-31.

19. Linden C, Alwis G, Ahlborg H, Gardsell P, Valdimarsson O, SteneviLundgren $S$, et al. Exercise, bone mass and bone size in prepubertal boys: one-year data from the pediatric osteoporosis prevention study. Scand J Med Sci Sports. 2007;17(4):340-7.

20. Linden C, Gärdsell P, Ahlborg H, Karlsson M. A School Curriculum Based Exercise Program Increase Bone Mineral Accrual in Boys and Girls During Early Adolescence-Four year data from the POP study (pediatric preventive osteoporotic study) J Bone Miner Res. 2005;20(1):75.

21. Lofgren B, Stenevi-Lundgren S, Linden C, Nilsson J, Karlsson M. A Three Years School Curriculum Based Exercise Program During Early Adolescence Increase Bone Mineral Accrual and Bone Size But Do Not Reduce the Fracture Risk - Fracture Data in 2005 Children in the Prospective Controlled Paediatric Osteoporosis Prevention (POP) Study. J Bone Miner Res. 2009;24 (Suppl 1). Available at [URL]. Accessed [09,19,2009].

22. MacKelvie KJ, Khan KM, Petit MA, Janssen PA, McKay HA. A schoolbased exercise intervention elicits substantial bone health benefits: a 2-year randomized controlled trial in girls. Pediatrics. 2003;112(6 Pt 1):e447.

23. MacKelvie K], Petit MA, Khan KM, Beck T], McKay HA. Bone mass and structure are enhanced following a 2-year randomized controlled trial of exercise in prepubertal boys. Bone. 2004;34(4):755-64.

24. McKay HA, Petit MA, Schutz RW, Prior JC, Barr SI, Khan KM. Augmented trochanteric bone mineral density after modified physical education classes: a randomized school-based exercise intervention study in prepubescent and early pubescent children. $J$ Pediatr. 2000;136(2):156-62.

25. Morris FL, Naughton GA, Gibbs JL, Carlson JS, Wark JD. Prospective ten-month exercise intervention in premenarcheal girls: positive effects on bone and lean mass. J Bone Miner Res. 1997;12(9):1453-62.

26. Nichols DL, Sanborn CF, Love AM. Resistance training and bone mineral density in adolescent females.J Pediatr. 2001;139(4):494-500.

27. Petit MA, McKay HA, MacKelvie KJ, Heinonen A, Khan KM, Beck TJ. A randomized school-based jumping intervention confers site and maturity-specific benefits on bone structural properties in girls: a hip structural analysis study. J Bone Miner Res. 2002;17(3):363-72.

28. Valdimarsson O, Linden C, Johnell O, Gardsell P, Karlsson MK. Daily physical education in the school curriculum in prepubertal girls during 1 year is followed by an increase in bone minera accrual and bone width--data from the prospective controlled Malmo pediatric osteoporosis prevention study. Calcif Tissue Int 2006;78(2):65-71.

29. Van Langendonck L, Claessens AL, Vlietinck R, Derom C, Beunen $\mathrm{G}$. Influence of weight-bearing exercises on bone acquisition in prepubertal monozygotic female twins: a randomized controlled prospective study. Calcif Tissue Int. 2003;72(6):666-74. 
30. Cummings SR, Nevitt MC, Browner WS, Stone K, Fox KM, Ensrud KE, et al. Risk factors for hip fracture in white women. Study of Osteoporotic Fractures Research Group. N Engl J Med. 1995;332(12):767-73.

31. Johnell O, Gullberg B, Kanis JA, Allander E, Elffors L, Dequeker J, et al. Risk factors for hip fracture in European women: the MEDOS Study. Mediterranean Osteoporosis Study. J Bone Miner Res. 1995;10(11):1802-15.

32. Jonsson B. Lyfe style and fracture risk. Thesis, University of Lund, Sweden. 1993.

33. Daly RM. The effect of exercise on bone mass and structural geometry during growth. Daly RM, Petit MA (eds) Optimizing bone mass and strength The role of physical activity and nutrition during growth, Karger. 2007;51:33-49.

34. Blimkie CJ, Rice S, Webber CE, Martin J, Levy D, Gordon CL. Effects of resistance training on bone mineral content and density in adolescent females. Can J Physiol Pharmacol.1996;74(9):1025-33.

35. Hind K, Burrows M. Weight-bearing exercise and bone mineral accrual in children and adolescents: a review of controlled trials. Bone. 2007;40(1):14-27.

36. Berard A, Bravo G, Gauthier P. Meta-analysis of the effectiveness of physical activity for the prevention of bone loss in postmenopausal women. Osteoporos Int.1997;7(4):331-7.

37. Heinonen A, Kannus P, Sievanen H, Oja P, Pasanen M, Rinne M, et al. Randomised controlled trial of effect of high-impact exercise on selected risk factors for osteoporotic fractures. Lancet. 1996;348(9038):1343-7.

38. Fiatarone MA, Marks EC, Ryan ND, Meredith CN, Lipsitz LA, Evans WJ. High-intensity strength training in nonagenarians. Effects on skeletal muscle. Jama.1990;263(22):3029-34.

39. Jarvinen TL, Sievanen H, Khan KM, Heinonen A, Kannus P. Shifting the focus in fracture prevention from osteoporosis to falls. $\mathrm{Bmj}$. 2008;336(7636):124-6.

40. Nilsson BE, Westlin NE. Bone density in athletes. Clin Orthop. 1971;77:179-82.

41. Karlsson M, Bass S, Seeman E. The evidence that exercise during growth or adulthood reduces the risk of fragility fractures is weak. Baillieres Best Pract Res Clin Rheumatol. 2001;15(3):429-50.

42. Bass S, Pearce G, Bradney M, Hendrich E, Delmas PD, Harding A, et al. Exercise before puberty may confer residual benefits in bone density in adulthood: studies in active prepubertal and retired female gymnasts. J Bone Miner Res. 1998;13(3):500-7.

43. Bass SL, Saxon L, Daly RM, Turner CH, Robling AG, Seeman E, et al. The effect of mechanical loading on the size and shape of bone in pre-, peri-, and postpubertal girls: a study in tennis players. J Bone Miner Res. 2002;17(12):2274-80

44. Warden SJ, Fuchs RK, Castillo AB, Nelson IR, Turner CH. Exercise when young provides lifelong benefits to bone structure and strength. J Bone Miner Res. 2007;22(2):251-9.

45. Cheng S, Sipila S, Taaffe DR, Puolakka J, Suominen H. Change in bone mass distribution induced by hormone replacement therapy and high-impact physical exercise in post-menopausa women. Bone. 2002;31(1):126-35.

46. Dencker M, Thorsson O, Karlsson MK, Linden C, Eiberg S, Wollmer $\mathrm{P}$, et al. Daily physical activity related to body fat in children aged 8-11 years. J Pediatr. 2006;149(1):38-42.

47. Clark EM, Ness AR, Tobias JH. Vigorous physical activity increases fracture risk in children irrespective of bone mass: a prospective study of the independent risk factors for fractures in healthy children. J Bone Miner Res. 2008;23(7):1012-22.

48. Tobias JH, Steer CD, Mattocks CG, Riddoch C, Ness AR. Habitual levels of physical activity influence bone mass in 11-year-old children from the United Kingdom: findings from a large population-based cohort. J Bone Miner Res. 2007;22(1):101-9.

49. Tveit M, Ahlborg H, Rosengren B, Nilsson J-Å, Karlsson M. Bone Loss and Fracture Risk after High Level of Physical Activity at Growth and Young Adulthood J Bone and Miner REs. 2010; 25(1)

50. Ruff CB, Walker A, Trinkaus E. Postcranial robusticity in Homo. III: Ontogeny. Am J Phys Anthropol. 1994;93(1):35-54.

51. Ducher G, Bass S. Exercise During Growth: Compelling Evidence for the Primary Prevention of Osteoporosis? BoneKEy. [Perspec- tives]. 2007;6(4):171-80.

52. Dyson K, Blimkie CJ, Davison KS, Webber CE, Adachi JD. Gymnastic training and bone density in pre-adolescent females. Med Sci Sports Exerc. 1997;29(4):443-50.

53. Ward KA, Roberts SA, Adams JE, Mughal MZ. Bone geometry and density in the skeleton of pre-pubertal gymnasts and school children. Bone. 2005;36(6):1012-8.

54. Haapasalo H, Kontulainen S, Sievanen H, Kannus P, Jarvinen M, Vuori I. Exercise-induced bone gain is due to enlargement in bone size without a change in volumetric bone density: a peripheral quantitative computed tomography study of the upper arms of male tennis players. Bone. 2000;27(3):351-7.

55. Kontulainen SA, Kannus PA, Pasanen ME, Sievanen HT, Heinonen $\mathrm{AO}, \mathrm{Oja} \mathrm{P}$, et al. Does previous participation in high-impact training result in residual bone gain in growing girls? One year follow-up of a 9-month jumping intervention. Int J Sports Med. 2002;23(8):575-81.

56. Duncan CS, Blimkie CJ, Kemp A, Higgs W, Cowell CT, Woodhead H, et al. Mid-femur geometry and biomechanical properties in 15 - to 18-yr-old female athletes. Med Sci Sports Exerc. 2002;34(4):673-81.

57. Greene DA, Naughton GA, Briody JN, Kemp A, Woodhead H, Corrigan $\mathrm{L}$. Bone strength index in adolescent girls: does physical activity make a difference? Br J Sports Med. 2005;39(9):622-7; discussion 7.

58. Ahlborg HG, Johnell O, Nilsson BE, Jeppsson S, Rannevik G, Karlsson MK. Bone loss in relation to menopause: a prospective study during 16 years. Bone. 2001;28(3):327-31.

59. Ahlborg HG, Johnell O, Turner CH, Rannevik G, Karlsson MK. Bone loss and bone size after menopause. NEngl JMed.2003;349(4):327-34

60. Turner CH, Burr DB. Basic biomechanical measurements of bone: a tutorial. Bone.1993;14(4):595-608.

61. Heinonen A, Sievanen H, Kannus P, Oja P, Vuori I. Site-specific skeletal response to long-term weight training seems to be attributable to principal loading modality: a pQCT study of female weightlifters. CalcifTissue Int. 2002;70(6):469-74.

62. Jones HH, Priest JD, Hayes WC, Tichenor CC, Nagel DA. Humeral hypertrophy in response to exercise. J Bone Joint Surg [Am] 1977;59(2):204-8.

63. Carlson KJ, Judex S. Increased non-linear locomotion alters diaphyseal bone shape. J Exp Biol. 2007;210(Pt 17):3117-25.

64. Hiney KM, Nielsen BD, Rosenstein D, Orth MW, Marks BP. Highintensity exercise of short duration alters bovine bone density and shape. J Anim Sci. 2004;82(6):1612-20.

65. Jones IE, Taylor RW, Williams SM, Manning PJ, Goulding A. Fouryear gain in bone mineral in girls with and without past forearm fractures: a DXA study. Dual energy X-ray absorptiometry. J Bone Miner Res. 2002;17(6):1065-72.

66. Macdonald HM, Kontulainen SA, Khan KM, McKay HA. Is a schoolbased physical activity intervention effective for increasing tibial bone strength in boys and girls? JBone Miner Res. 2007;22(3):434-46.

67. Karlsson M, Nilsson JA, Sernbo I, Redlund-Johnell I, Johnell O, Obrant KJ. Changes of bone mineral mass and soft tissue composition after hip fracture. Bone. 1996;18(1):19-22.

68. Karlsson MK, Hasserius R, Obrant KJ. Bone mineral density in athletes during and after career: a comparison between loaded and unloaded skeletal regions. Calcif Tissue Int. 1996;59(4):245-8.

69. Gafni RI, Baron J. Childhood bone mass acquisition and peak bone mass may not be important determinants of bone mass in late adulthood. Pediatrics. 2007;119 Suppl 2:S131-6.

70. Gunter KB, Baxter-JOnes A, Mirwald R, Almstedt HC, Durski S Fuller-Hayes AA, et al. Jump starting skeletla health: bone increases from jumping exercise persist seven years post intervention. J Bone Min Res. 2007;22 Suppl 1:S:506.

71. Eser P, Hill B, Ducher G, Bass S. The long-term macro-architectural benefits of high impact exercise during growth: a styd of retired gymnasts. J Bone Min Res. 2007;22 (Suppl 1):S:486.

72. Nordstrom A, Karlsson C, Nyquist F, Olsson T, Nordstrom P, Karlsson $\mathrm{M}$. Bone loss and fracture risk after reduced physical activity. J Bone Miner Res. 2005;20(2):202-7.

73. Valdimarsson O, Alborg HG, Duppe H, Nyquist F, Karlsson M. Reduced training is associated with increased loss of BMD.J Bone 
Miner Res. 2005;20(6):906-12.

74. Kontulainen S, Kannus P, Haapasalo H, Heinonen A, Sievanen H, Oja $\mathrm{P}$, et al. Changes in bone mineral content with decreased training in competitive young adult tennis players and controls: a prospective 4-yr follow-up. Med Sci Sports Exerc. 1999;31(5):646-52.

75. Michel BA, Lane NE, Bjorkengren A, Bloch DA, Fries JF. Impact of running on lumbar bone density: a 5-year longitudinal study. J Rheumatol.1992;19(11):1759-63.

76. Vuori I, Heinonen A, Sievanen H, Kannus P, Pasanen M, Oja P. Effects of unilateral strength training and detraining on bone mineral density and content in young women: a study of mechanical loading and deloading on human bones. Calcif Tissue Int. 1994;55(1):59-67.

77. Karlsson MK, Linden C, Karlsson C, Johnell O, Obrant K, Seeman E. Exercise during growth and bone mineral density and fractures in old age. Lancet. 2000;355(9202):469-70.

78. Duppe H, Gardsell P, Johnell O, Ornstein E. Bone mineral density in female junior, senior and former football players. Osteoporos Int. 1996;6(6):437-41.

79. Karlsson KM, Karlsson C, Ahlborg HG, Valdimarsson O, Ljunghall $\mathrm{S}$. The duration of exercise as a regulator of bone turnover. Calcif Tissue Int. 2003;73(4):350-5.

80. Karlsson MK, Johnell O, Obrant KJ. Bone mineral density in weight lifters. Calcif Tissue Int. 1993;52(3):212-5.

81. Karlsson MK, Johnell O, Obrant KJ. Is bone mineral density advantage maintained long-term in previous weight lifters? Calcif Tissue Int. 1995;57(5):325-8.

82. Karlsson MK, Johnell O, Obrant KJ. Bone mineral density in professional ballet dancers. Bone Miner.1993;21(3):163-9.

83. Khan KM, Green RM, Saul A, Bennell KL, Crichton KJ, Hopper JL, et al. Retired elite female ballet dancers and nonathletic controls have similar bone mineral density at weightbearing sites. J Bone Miner Res. 1996;11(10):1566-74.

84. Riggs BL, Melton Iii LJ, 3rd, Robb RA, Camp JJ, Atkinson EJ, Peterson JM, et al. Population-based study of age and sex differences in bone volumetric density, size, geometry, and structure at different skeletal sites. J Bone Miner Res. 2004;19(12):1945-54.

85. Linden C, Ahlborg H, Gardsell P, Valdimarsson O, Stenevi-Lundgren S, Besjakov J, et al. Exercise, bone mass and bone size in prepubertal boys: one-year data from the pediatric osteoporosis prevention study. Scand J Med Sci Sports. 2006.

86. Linden C, Ahlborg HG, Besjakov J, Gardsell P, Karlsson MK. A school curriculum-based exercise program increases bone mineral accrual and bone size in prepubertal girls: two-year data from the pediatric osteoporosis prevention (POP) study. J Bone Miner Res. 2006;21(6):829-35.

87. Specker B, Binkley T. Randomized trial of physical activity and calcium supplementation on bone mineral content in 3- to 5-year-old children. J Bone Miner Res. 2003;18(5):885-92.

88. Specker B, Binkley T, Fahrenwald N. Increased periosteal circumference remains present 12 months after an exercise intervention in preschool children. Bone. 2004;35(6):1383-8.

89. Karlsson MK, Alborg HG, Obrant K, Nyquist F, Lindberg H, Karlsson C. Exercise during growth and young adulthood is associated with reduced fracture risk in old ages.J Bone Miner Res. 2002;17 suppl 1:s297.

90. Huddleston AL, Rockwell D, Kulund DN, Harrison RB. Bone mass in lifetime tennis athletes. Jama.1980;244(10):1107-9.

91. Wyshak G, Frisch RE, Albright TE, Albright NL, Schiff I. Bone fractures among former college athletes compared with nonathletes in the menopausal and postmenopausal years. Obstet Gynecol.1987;69(1):121-6.

92. Laing EM, Wilson AR, Modlesky CM, O'Connor PJ, Hall DB, Lewis $\mathrm{RD}$. Initial years of recreational artistic gymnastics training improves lumbar spine bone mineral accrual in 4- to 8-year-old females. J Bone Miner Res. 2005;20(3):509-19.

93. Mackelvie KJ, McKay HA, Khan KM, Crocker PR. A school-based exercise intervention augments bone mineral accrual in early pubertal girls. J Pediatr. 2001;139(4):501-8.

94. McKay HA, MacLean L, Petit M, MacKelvie-O'Brien K, Janssen P, Beck T, et al. "Bounce at the Bell": a novel program of short bouts of exercise improves proximal femur bone mass in early pubertal children. BrJ Sports Med. 2005;39(8):521-6.

95. Witzke KA, Snow CM. Effects of plyometric jump training on bone mass in adolescent girls. Med Sci Sports Exerc. 2000;32(6):1051-7.

96. Stear SJ, Prentice A, Jones SC, Cole TJ. Effect of a calcium and exercise intervention on the bone mineral status of 16-18-y-old adolescent girls. Am J Clin Nutr. 2003;77(4):985-92. 